\title{
Evaluation of Buffalo Bull Semen for Some Venereal Diseases Using PCR
}

\author{
K. A. Abd El-Razik*, Karima Gh. M. Mahmoud*, A. M. Sakr**, A. S. A. Sosa*, \\ M. H. Hasanain*, Y. F. Ahmed* and M. F. Nawito* \\ *Department of Animal Reproduction \& Artficial Insemination, National Research \\ Centre and **Department of Biotechnology, Animal Production Research Institute, \\ Cairo, Egypt.
}

\begin{abstract}
RTIFICIAL INSEMINATION using unaccredited frozen semen is a major approach $A$ for diseases transmission. This work intended to scan the buffalo bull semen for $\mathrm{Br}$. melitensis, Toxoplasma gondii and Neospora caninum using Polymerase Chain Reaction (PCR). Fifty bulls were used in this study. Semen was assessed for volume, motility, viability, and chromatin damage. Total genomic DNA was extracted from buffalo semen and amplified by PCR. The results showed that, semen samples were positive to Toxoplasma gondii in 6\% of the semen samples, while all the semen samples were totally negative to Br.Melitensis and Neospora caninum. No significant differences were found in semen characteristics between bulls positive or negative to Toxoplasma gondii.

In conclusion, the present trial suggests the opportunity of venereal transmission of $T$. gondii among buffaloes. However, further investigations are required using high number of semen samples from different localities of Egypt.
\end{abstract}

Keywords: Buffalo bull, semen characteristics, PCR, Brucella melitensis, Toxoplasma gondii, Neospora caninum.

\section{Introduction}

Control of pathogens in semen from bulls at artificial insemination centers (AICs) is mainly relied on regular testing for both the pathogen antigen as well as antibody reaction to the disease [1]. To diminish the opportunity of disease spread, criteria for the production of semen from donor bulls have been customized and bulls must be verified to qualify for entry into an AIC and be constantly monitored during semen production. Testing programs to screen donor bulls in AICs are evaluated to reduce the possibility of diseases dissemination through frozen semen $[1,2]$.

Brucellosis in animals is a bacterial infectious and zoonotic disease. In cattle, brucellosis is frequently caused by Brucella abortus, less commonly by $B$. melitensis and infrequently by $B$. suis [3]. The disease is characterized by abortion, retention of placenta, orchitis and epididymitis [3]. The Brucella pathogens are excreted in semen of infected bulls and the disease may be transferred to healthy cows through contaminated semen used in artificial insemination [4]. Therefore, control of spread of brucella pathogen, through frozen semen could be vital in artificial insemination centers [5].

Toxoplasma gondii is an intracellular protozoon and can infect all warm blooded animal species. Toxoplasmosis has health and veterinary importance, responsible for abortions and congenital disease in many intermediate host species [6]. T. gondii was isolated from semen samples of experimentally infected goats [7,8] and sheep [9] proposing

*Corresponding Author: K.A. Abd El-Razik, E.mail address: khaled707@hotmail.com National Research Centre, Dokki, Tahrir Street, 12622 Giza, Egypt

DOI: $10.21608 /$ ejvs.2017.1850.1021

(C)2017 National Information and Documentation Centre (NIDOC) 
transmission of $T$. gondii by the venereal path. Although T. gondii had positively isolated from the cattle semen by PCR technique [10], there are no studies in the literature concerning sexual transmission of this protozoon in buffalo.

Preventing of $N$. caninum in semen is a chief objective of control platforms as it is a contributing agent of abortion allover the world [11]. Neospora caninum is a universal distributed obligate intracellular protozoan. It is considered as the most significant causative agent of recurrent abortions in dairy cattle in several countries and has developed adverse economic impact for their breeding, including reduced milk production, those attributed to extend calving interval, dropping stock value and raised culling rate among others [12]. Furthermore, $N$. caninum may cause disease in calves infected during pregnancy [13]. At birth these calves may have neurological signs, being below weight, missing capability to rise, or have no clinical signs [14]. N. caninum infection may also reduce milk production and condensed production life due to early discarding [15].

Hence, bulls' semen and artificial insemination are important ways for transmission of many diseases causing abortion in female animals, so this work aimed to examine the buffalo bull semen using polymerase chain reaction for Br.melitensis, T. gondii and N. caninum.

\section{Materials and Methods}

\section{Bulls and semen samples}

Total of 50 bulls were used in this study, semen samples were collected by artificial vagina from apparently healthy breeding buffalo bulls maintained at breeding station at Mahalet Mussa near to Sakha, Kafr el-Sheikh Governorate. Semen samples were evaluated and transported on ice to the laboratory and stored at $-20{ }^{\circ} \mathrm{C}$ until further use.

\section{Semen evaluation}

Volume of the ejaculate, individual motility, live sperm percentage using eosin-nigrosin staining and chromatin integrity using acridine orange staining were recorded for the bulls.

Extraction of bacterial and parasitic DNA from buffalo semen

Total genomic DNA was extracted from buffalo semen using a QIAamp DNA Mini Kit (QIAGEN GmbH, Germany)according to the manufacturer's protocol with minor modifications as reported by Pawar et al. [16] and Hasanain et al. [17]. Briefly, $10 \mu \mathrm{l}$ of fresh semen and pellets of one frozen semen straw was diluted with 190 $\mu 1$ of phosphate-buffered saline prior to lysis with proteinase $\mathrm{K}$ and lysis buffer. The lysate was passed through spin column. Two washings were done with then the DNA was eluted in 20 $\mu 1$ nuclease-free water and stored at $-80^{\circ} \mathrm{C}$ until further use.

\section{Polymerase Chain Reaction (PCR)}

Oligonucleotide primers were selected from the gene encoding $31 \mathrm{KDa}$ protein of $\mathrm{Br}$. Melitensis,B1gene of T. gondii and N. caninum. Total of $50 \mu \mathrm{l}$ volume containing $1 \mu \mathrm{l}$ of each primer alone (100 pmol) shown in Table 1, 25 $\mu 1$ of 2X Taq Master Mix (Cat. No. PLMM01, Vivantis Co., Malaysia) and $2 \mu \mathrm{l}$ of each DNA sample. PCR was performed in a Bio-Rad T100 thermocycler which was programmed as in Table 1. PCR product was electrophoresed and examined using UV transilluminator. Positive controls (pure cultures) and negative controls (double distilled water) were used.

\section{Statistical analysis}

Data were analyzed using the SPSS version 16.0. Student's t test was performed to compare between positive and negative toxoplasmosis buffalo bulls. Differences were considered to be significant at $\mathrm{P}<0.05$. 
TABLE 1. PCR primers, conditions and expected PCR products for Br. melitensis, T.gondii and $N$. caninum.

\begin{tabular}{|c|c|c|}
\hline Target & Primer Sequence\&PCR Product & Program \\
\hline $\begin{array}{l}\text { Br.melitensis } \\
{[18]}\end{array}$ & $\begin{array}{l}\text { B1 TGGCTCGGTTGCCAATATCAA } \\
\text { B2CGCGCTTGCCTTTCAGGTCTG } \\
\text { The expected product ( } 323 \mathrm{bp} \text { ) }\end{array}$ & $\begin{array}{lr}\text { Init.Denat. } & 93^{\circ} \mathrm{C} \text { for } 5 \mathrm{~min} \\
\text { Denat. } & 92^{\circ} \mathrm{C} \text { for } 1 \mathrm{~min} \\
\text { Anneal. } & 60^{\circ} \mathrm{C} \text { for } 1 \mathrm{~min} \\
\text { Extension } & 72^{\circ} \mathrm{C} \text { for } 1 \mathrm{~min} \\
\text { repeat for } 40 \text { cycles } \\
\text { Final Extension } \quad 72^{\circ} \mathrm{C} \text { for } 10 \mathrm{~min}\end{array}$ \\
\hline $\begin{array}{l}\text { T.gondii } \\
{[19]}\end{array}$ & $\begin{array}{l}\text { B1TGCATAGGTTGCAGTCACTG } \\
\text { B2GGCGACCAATCTGCGAATACACC } \\
\text { The expected product }(94 \mathrm{bp})\end{array}$ & $\begin{array}{ll}\text { Init.Denat. } & 93^{\circ} \mathrm{C} \text { for } 3 \mathrm{~min} \\
\text { Denat. } & 93^{\circ} \mathrm{C} \text { for } 10 \mathrm{sec} \\
\text { Anneal. } & 62.5^{\circ} \mathrm{C} \text { for } 10 \mathrm{sec} \\
\text { Extension } & 72^{\circ} \mathrm{C} \text { for } 15 \mathrm{sec} \\
\text { repeat for } 40 \text { cycles } \\
\text { Final Extension } \quad 72^{\circ} \mathrm{C} \text { for } 7 \mathrm{~min}\end{array}$ \\
\hline $\begin{array}{l}\text { N.caninum } \\
{[20]}\end{array}$ & $\begin{array}{l}\text { Np21GTGCGTCCAATCCTGTAAC } \\
\text { Np6 CAGTCAACCTACGTCTTCT } \\
\text { The expected product (328bp) }\end{array}$ & $\begin{array}{ll}\text { Init.Denat. } & 94^{\circ} \mathrm{C} \text { for } 5 \mathrm{~min} \\
\text { Denat. } & 94^{\circ} \mathrm{C} \text { for } 1 \mathrm{~min} \\
\text { Anneal. } & 50^{\circ} \mathrm{C} \text { for } 1 \mathrm{~min} \\
\text { Extension } & 72^{\circ} \mathrm{C} \text { for } 2 \mathrm{~min} \\
\text { repeat for } 40 \text { cycles } \\
\text { Final Extension } \quad 72^{\circ} \mathrm{C} \text { for } 8 \mathrm{~min}\end{array}$ \\
\hline
\end{tabular}

\section{Results}

Semen samples collected from breeding station at Mahalet Mussa near to Sakha, Kafr elSheikh Governorate were positive to T.gondii in $3(6 \%)$ out of the 50 semen samples (Fig. 1A). On the contrary all the semen samples were completely negative to Br. Melitensis (Fig. 1B) and N. caninum (Fig. 1C) using PCR.

Data presented in Table 2 showed that, ejaculate volume, individual motility, live sperm percentage and chromatin integrity were not significantly differ between T. gondii-ve and T.gondii +ve bulls.

\section{Discussion}

Diagnostic approaches such as microbiological isolation and identification of organisms and nucleic acid amplification built techniques have been applied for revealing of brucella pathogens in bull semen [3]. Although microbiological isolation is the gold standard for brucella detection in semen, this technique is time consuming and there is hazard to laboratory personnel. A sensitive nucleic acid built method, polymerase chain reaction has been used in recognition of brucella genomic DNA in bovine semen [4, 21, 22]. Slight. expert personnel (for reaction set up and result investigation) limit PCR technique being used as a classical diagnostic test for Brucellosis under field situation and less equipped laboratories at breeding bull stations.

In the present study, all the buffalo semen samples were totally negative to Br. melitensis. In contrast, Dehkordi et al. [23] recorded 24.50\% and $3.92 \%$ in bovine semen samples while $15.38 \%$ and $1.09 \%$ in buffalo semen samples were positive for Brucellaabortus and Brucella melitensis respectively.

In the current study, the semen samples were positive to toxoplasmosis in $3(6 \%)$ out of the 50 semen samples. This was agreed by Scarpelli et al. [10] who revealed the existence of the parasite in semen samples of animals infected with oocysts (GI) and tachyzoites (GII) which suggest the opportunity of sexual transmission of $T$. gondii in the bovine species. This also was supported by the isolation of $T$. gondii in the semen of sheep [9], goats [24] and swine [25]. Moreover, the $T$. gondii DNA was identified in tissues of stillborns

Egypt. J. Vet. Sci. Vol. 48, No.2 (2017) 


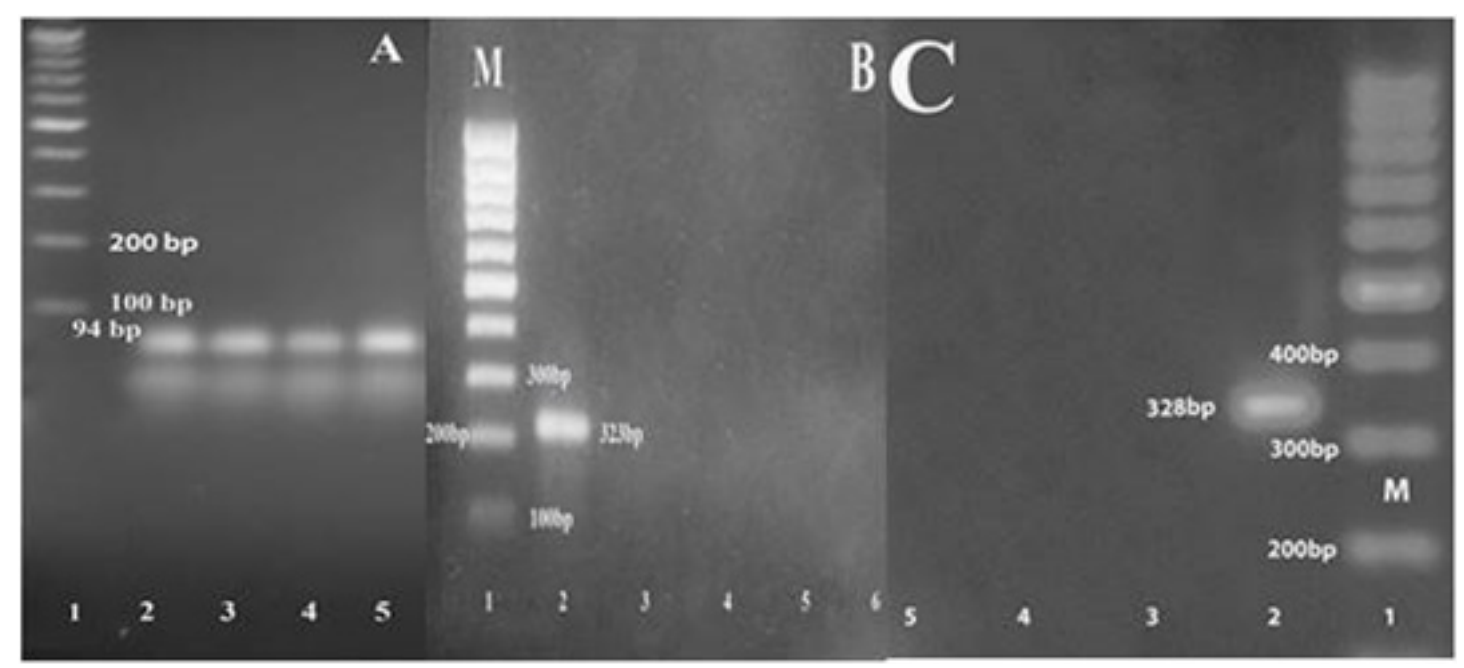

Fig.1. PCR targeting T.gondii from bulls semen DNA(1-A) . Lane 1: 100 bp molecular size marker. Lane2: positive control, Lanes 3-5: $T$.gondii PCR products from bulls semen DNA samples (94bp). PCR targeting Br. melitensis (1-B) \& N.caninum (1-C) from Bulls semen DNA. Lane 1: 100 bp molecular size marker. Lane 2: positive controls, Lanes 3-5: PCR amplification of bulls semen DNA samples.

TABLE 2. Effect of toxoplasmosis on fresh semen characteristics of buffalo bulls (Mean \pm SE).

\begin{tabular}{|c|c|c|c|c|}
\hline Bulls & $\begin{array}{c}\text { Ejaculate } \\
\text { volume(ml) }\end{array}$ & $\begin{array}{c}\text { Individual } \\
\text { motility \% }\end{array}$ & Live sperm \% & $\begin{array}{c}\text { Chromatin } \\
\text { damage \% }\end{array}$ \\
\hline T. gondii-ve & $3.3 \pm 0.7$ & $80.5 \pm 1.2$ & $85.3 \pm 1.2$ & $0.6 \pm 0.1$ \\
\hline$T$. gondii $+\mathrm{ve}$ & $2.9 \pm 0.04$ & $79.3 \pm 0.5$ & $83.0 \pm 0.7$ & $0.5 \pm 0.1$ \\
\hline
\end{tabular}

and placenta of sheep inseminated with infected semen suggesting the potential infection by contaminated semen [9].

With regard to semen analysis, no significant differences in all studied semen characteristics between bulls positive and negative to toxoplasmosis. To our knowledge, there are no studies in buffalos registered a correlation between toxoplasmosis and semen parameters. In this respect, Barakat et al. [26] recorded low quality semen of rabbits infested with $T$. gondii. In Egypt, high seroprevalence of toxoplasmosis and neosporosis in cattle were recorded by Ibrahim et al. [27]. So, it is essential to test the animals annually or semi-annually especially bulls in AIC centers to monitor the disease status.

In the present study, $N$. caninum infection is not reported in buffalo semen. The chance of $N$. caninum transmission by semen can indicate great depth repercussions on cattle semen trade.

Egypt. J. Vet. Sci. Vol. 48, No.2 (2017)
Sharifzadeh et al. [12] reported higher percentage (17.14\%) of semen samples $(9.71 \%$ and $7.43 \%$ of fresh and frozen semen) in Iranian bulls infected with $N$. caninum using PCR that lead to raise possibility of the disease spreading. Moreover, $10.53 \%$ of positive samples for $N$. caninum were recorded by Doosti et al. [28] in bovine frozen semen used for artificial insemination. The presence of $N$. caninum DNA in semen from naturally infected bulls was also reported by Ortega-Mora et al. [29] and proved the probability of $N$. caninum transmission by semen.

In conclusion, the present finding demonstrated the possibility of toxoplasmosis transmission by buffalo semen. Further testing may be needed relying on the predominant diseases such as brucellsosis and neosporosis.

\section{Conflict of interest}

None. 


\section{Acknowledgments}

This study was supported by National Research Centre, Cairo, Egypt, project number P101205.

\section{References}

1. Hopper, R.M. (2015) “Bovine Reproduction”, $1^{\text {st }}$ ed., Chapter 73, Control of Semen-borne Pathogens, Rory Meyer, published by John Wiley \& Sons, Inc.

2. Philpott, M. (1993)The dangers of disease transmission by artificial insemination and embryo transfer. Br. Vet. J., 149, 339-369.

3. OIE (2009) Bovine brucellosis. OIE Terrestrial Manual 2009, Chapter 2.4.3

4. Amin, A.S., Hamdy, M.E.R. and Ibrahim, A.K. (2001) Detection of Brucella melitensis in semen using the polymerase chain reaction. Vet. Microbiol., 83, 37-44.

5. Prusty, B.R., Chaudhuri P., Chaturvedi, V.K., Saini, M., Mishra, B.P. and Gupta, P.K. (2016) Visual Detection of Brucella spp. in Spiked Bovine Semen Using Loop-Mediated Isothermal Amplification (LAMP), Assay, Ind. J. Microbiol., 56, 142-147.

6. Tenter, A.M., Heckeroth, A.R. and Weiss, L.M. (2000) Toxoplasma gondii: from animals to humans. Int. J. Parasitol., 30, 1217-1258.

7. Santana, L.F., Costa A.J., Pieroni J., Lopes W.D.Z., Santos R.S., Oliveira G.P., de Mendonça R.P. and Sakamoto, C.A.M. (2010) Detection of Toxoplasma gondii in the reproductive system of male goats. Rev. Bras .Parasitol. Vet., Jaboticabal., 19, 179-182.

8. Santana, L.F., Rossi, G.A.M., Gaspar, R.C., Oliveira, G.P. and Costa, A.J. (2013) Evidence of sexual transmission of Toxoplasma gondii in goats. Small Rum. Res., 115, 130-133.

9. de Moraes, E.P.B.X., Batista, A.M., Faria, E.B., Freire, R.L., Freitas, A.C., Silva, M.A.R., Braga, V.A. and Mota, R.A. (2010) Experimental infection by Toxoplasma gondii using contaminated semen containing different doses of tachyzoites in sheep. Vet. Parasitol., 170, 318-322.
10. Scarpelli, L.C., Lopes, W.D.Z., Migani, M., Bresciani, K.D.S and Costa, A.J. (2009) Toxoplasma gondii in experimentally infected Bos Taurus and Bos indicus semen and tissues. Braz. J. Vet. Res. An. Sci., 29, 59-64.

11. Jenkins, M., Baszler, T., Bjorkman, C., Schares, G. and Williams, D. (2002) Diagnosis and seroepidemiology of Neospora caninumassociated bovine abortion. Int. J. Parasitol., 32, 631-636.

12. Sharifzadeh, A., Doosti, A. and Dehkordi, P.G. (2012) PCR assay for detection of Neospora caninum in fresh and frozen semen specimens of Iranian bulls. World Appl. Sci. J., 17, 742-749.

13. Barr, B.C., Anderson, M.L., Blanchard, P.C., Daft, B.M., Kinde, H. and Conrad, P.A. (1990) Bovine fetal encephalitis and myocarditis associated with protozoal infections. Vet. Pathol., 27, 354-361.

14. Dubey, J.P. and Schares, G. (2011) Neosporosis in animals-the last five years. Vet. Parasitol., 180, 90-108.

15. Thurmond, M.C. and Hietala, S.K. (1997) Effect of Neospora caninum infection on milk production in first-lactation dairy cows. J. Am. Vet. Med. Assoc., 210, 672-674.

16. Pawar, S.S., Meshram, C.D., Singh, N.K., Sonwane, A.A. , Saini, M. , Rautmare, S.S., Muglikar, D.M. , Mishra, B.P. and Gupta, P.K. (2014) Rapid detection of bovine herpes virus 1 in bovine semen by loop-mediated isothermal amplification (LAMP) assay. Arch Virol., 159, 641- 648.

17. Hasanain, M.H., Mahmoud, K.Gh.M., Ahmed, Y.F., El-Menoufy, A.A., Sakr, A.M. and Othman, O.E. (2017) Effect of body condition score and PCR-RFLP polymorphism of prolactin gene on semen characteristics of buffalo bulls (Bubalus Bubalis). Egypt. J. Vet. Sci., 48, 1-9.

18. Baily, G.G., Krahn, J.B., Drasar, B.S. and Stoker, N.G. (1992) Detection of B. melitensis and B. abortus by DNA amplification. J. Trop. Med. Hyg., 95, 271-275.

19. Burg, J.L., Grover, C.M., Pouletty, P. and Boothroyd, J.C. (1989) Direct and sensitive detection of a pathogenic protozoan, Toxoplasma gondii, by polymerase chain reaction. J. Clin. Microbiol., 27, 1787-1792.

Egypt. J. Vet. Sci. Vol. 48, No.2 (2017) 
20. Liddel, S., Jenkins, M.C. and Dubey, J.P.(1999) A competitive PCR assay for quantitative detection of Neospora caninum. Int. J. Parasitol., 29, 1583-1587.

21. Vinodh, R., Raj, GD., Govindarajan, R. and Thiagarajan, V. (2008) Detection of Leptospira and Brucella genomes in bovine semen using polymerase chain reaction. Trop. Anim. Health, 40, 323-329.

22. Junqueira Junior, D.G., Rosinha, G.M.S., Carvalho, C.E.G., Oliveira, C.E., Sanches, C.C. and Lima-Ribeiro, A.M.C. (2013) Detection of Brucella spp. DNA in the semen of seronegative bulls by polymerase chain reaction. Transbound. Emerg. Dis., 6, 376377.

23. Dehkordi, F.S., Khamesipour, F. and Momeni, M. (2014) Brucella abortus and Brucella melitensis in Iranian bovine and buffalo semen samples, The first clinical trial on seasonal, senile and geographical distribution using culture, conventional and real-time Polymerase Chain Reaction assays. Kafkas Univ. Vet. Fok. Derg., 20, 821-828.

24. Dubey, J.P. and Sharma, S.P. (1980) Parasitemia and tissue infection in sheep fed Toxoplasma gondii oocysts. J. Parasitol., 66, 111-119.

25. Moura, A.B., Costa, A.J., Filho, J.S., Paim, B.B., Pinto, F.R. and Di Mauro, D.C. (2007) Toxoplasma gondii in semen of experimentally infected swine. Pesq. Vet. Bras., 27, 430-434.

26. Barakat. A.M.A, El-Nattat.W.S., Desouky, H.M, Abdel-Razik, K.A and Mahmoud, K.Gh.M. (2006) Molecular aspects, seminal, chromosomal, hormonal and pathological changes in rabbit-bucks experimentally infected with Toxoplasma gondii. Egypt. J. Basic Appl. Physio., 5, 59-76.

27. Ibrahim, H.M., Huang, P., Salem T.A., Talaat R.M., Nasr M.I., Xuan X. and Nishikawa, Y. (2009) Short Report: Prevalence of Neospora caninum and Toxoplasma gondii Antibodies in Northern Egypt. Am. J. Trop. Med. Hyg., 80, 263-267.
28. Doosti, A., Khamesipour, F., Nekoei, S. and Lutvikadic, I.(2015)Survey for the presence of Neospora caninum in frozen bull's semen samples by PCR assay. Asian Pac. J. Trop. Dis., 5, 7-12.

29. Ortega-Mora, L.M., Ferre, I., del-Pozo, I., Caetano-da-Silva, A., Collantes-Ferna'ndez, E., Regidor-Cerrillo, J., Ugarte-Garagalza, C. and Aduriz G. (2003) Detection of Neospora caninum in semen of bulls. Vet. Parasitol., 117, 301-8. 


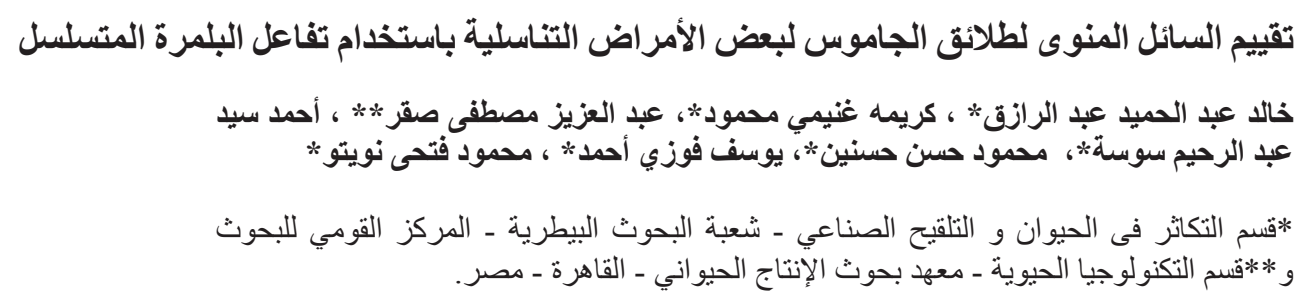

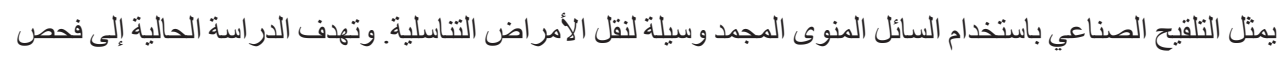

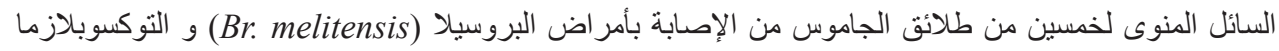

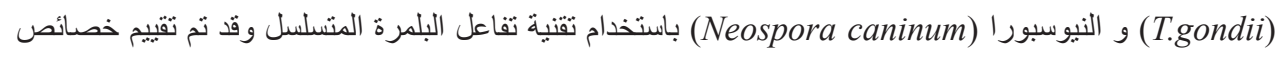

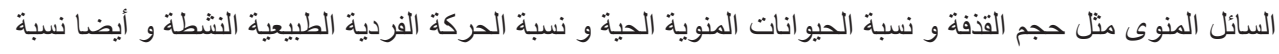
سلامة الكروماتين. وقد تم استخلاص الحمض النووى الديوكسى ريبوزى من عينات السائل المنوى و اكثاره باستخدام

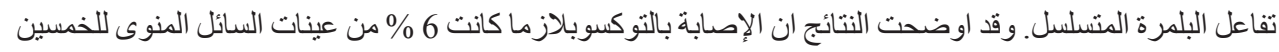

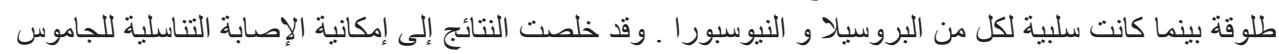

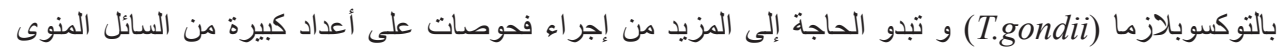

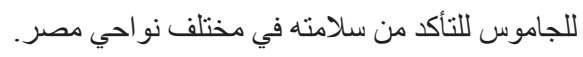

الكلمات الدالة : طلائق الجاموس، مواصفات السائل المنوي، تفاعل البلمرة المتسلسل، بروسيلا مبلتنسس، توكسوبلازما جوندى، نيوسبور ا كانينم. 